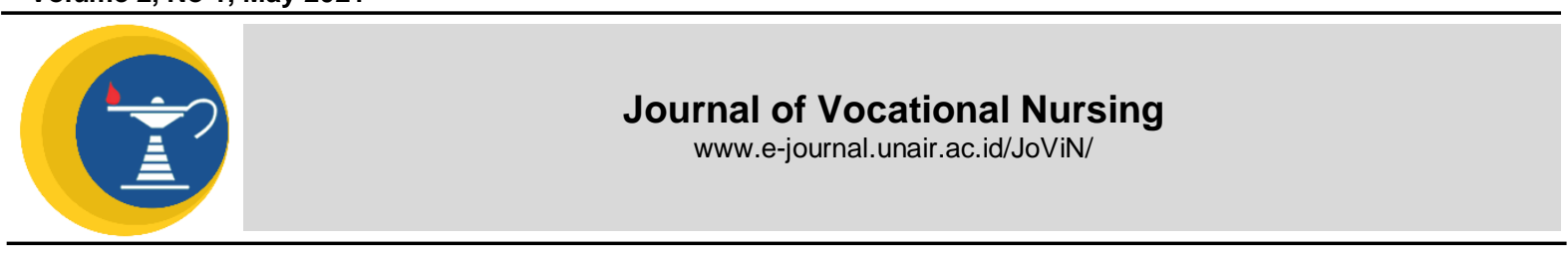

\title{
DESCRIPTION OF KNOWLEDGE ABOUT THE POST PLACENTA IUD (INTRA UTERINE DEVICE) CONTRACEPTIVE METHOD FOR PREGNANT
}

\author{
Lailatul Fadliyah, Amellia Mardhika, Emuliana Sulfat, Iswatun, Endah S. \\ W, and Nela A. S \\ Faculty of Vocational Studies, Universitas Airlangga
}

Research Report

\section{A B STRACT}

Introduction: Post-placental IUD is a long-term contraceptive method with an effective pregnancy prevention 0.6-0.8 pregnancies / 100 women. Installation that is carried out when the mother gives birth has an impact on the coverage of contraceptive use from an early age. Post-placental IUD contraceptives are not only effective in the long term for up to 10 years but are also affordable contraceptives for people from low to high economies status. Currently, these contraceptives can be purchased or installed for free. Contraception does not interfere with milk production, does not require routine follow-up to the hospital, contraceptive examinations can be done independently. The purpose of this study was to describe the knowledge about the post-placenta IUD contraceptive method. Methods: This study used a descriptive design, with a population of 98 people and a sample of 54 people. The sampling used is purposive sampling. Collecting data with a closed questionnaire. Data processing and data analysis by editing, scoring, coding, tabulating and presented in narrative form then draw conclusions. Results: Based on the results of the study, it was found that most (78.1\%) pregnant women had less knowledge about Post Placenta IUD contraception. Conclusion: The reference of this study is to increase knowledge about the Post Placenta IUD (Intra Uterine Device) contraceptive method in pregnant women. Periodic health education regarding this contraceptive method during pregnancy so that at delivery, post placenta IUD contraception can be immediately installed.
ARTICLE INFO

Received April 05, 2021

Accepted May 30, 2021

Online May 31, 2020

*Correspondence:

Lailatul Fadliyah

*Email:

fadliyahlaila@vokasi.unair.ac.id

\section{INTRODUCTION}

Indonesia ranks 4 th in the world by population after India, China and America (UNDESA, 2019). With such a high population, management is needed to control it, namely the contraceptive method that has been proclaimed by the Indonesian government. The Post Placenta IUD (Intra Uterine Device) contraceptive method is a device that is an object that is inserted into the uterus of a woman aged 20-40 years old, functions to prevent conception. These contraceptives are very effective, reversible and can last up to 10 years of use. (Abdul Barri, 2013). The use of the Post Placenta IUD (Intra Uterine Device) contraceptive method is still rarely in demand by mothers of reproductive age. Data from BKKBN, 2013 indicate that this contraceptive method ranks 4th after injections, pills and implants. In fact, when viewed from the duration of use and effectiveness, it is higher than the contraceptive injection and the birth control pill.

The Ministry of Health (2013) states that the Post Placenta IUD (Intra Uterine Device) contraceptive method is needed for postpartum mothers considering that the unexpected return of female fertility can sometimes occur before menstruation arrives. Ovulation averages at 45 days postpartum or even earlier for mothers who do not breastfeed their babies. Two out of three mothers who do not breastfeed will experience menstruation before the arrival of menstruation (Ministry of Health, 2013).

Cognitive knowledge is a very important domain in shaping one's actions (overt behavior). According to Notoatmodjo 2011 knowledge has six levels, namely 1). Know (know), 2) understand (comprehension), 3). Application (application), 4). Analysis (analiysis), 5. Synthesis (synthesis) and 
evaluation (evaluation). Factors that can affect the level of knowledge of a postpartum mother who does not use contraception include: education, parity, and age.

Education is one of the factors that can affect knowledge, with education, someone will easily absorb or understand the knowledge they get. Education, you can develop or improve certain abilities including understanding the concept of the Post Placenta IUD (Intra Uterine Device) contraceptive method properly. Increasing knowledge through health education for prospective acceptors is important provided by health workers or midwives

Age can affect a person's knowledge, the older a person is, the better his mental development processes are. One person's memory is also influenced by the age of A Hary, Wied. (2011). The more you get older, the more information you get about the Post Placenta IUD (Intra Uterine Device) contraceptive method, the more you will understand this contraceptive method.

Parity is the number of live births a woman has (BKKBN, 2011). The more mothers have children, the more experienced they will be in following contraception. The mother will increasingly understand the contraceptive method that suits her, including this post placenta IUD contraceptive method.

The impact that can arise due to post partum mothers not having sufficient knowledge about this post placenta IUD contraceptive method, it can occur early pregnancy or immediately after delivery. The condition of newborn babies does not get many opportunities to get sufficient breast milk because the mother is already pregnant with her next child. Maternal health cannot be maximized due to immediately preparing for another pregnancy, from a psychological point of view, the mother will also experience high stress because the child is still young and will have the next child.

In order to anticipate the above, the role of health workers needs to provide health education about immediate contraceptive methods that can be used immediately after delivery, namely the Post Placenta IUD (Intra Uterine Device) contraceptive method. Education can be done when pregnant women do antenatal care at a midwife, clinic, or health center.

Roles are a set of behaviors expected by others towards someone according to their position in a system (Wahit lqbal Mubarok, 2005). The family is the smallest unit of society consisting of the head of the family and several people who gather and live in a place under one roof (Sudiharto, 2007). With continuing education to prospective acceptors and families, it is hoped that it can provide support and increase knowledge about the post IUD contraceptive method. placenta, so you can choose this method of contraception.

From the description above, the authors conducted research on the knowledge of pregnant women about the Post Placenta IUD (Intra Uterine Device) contraceptive method.

\section{MATERIALS AND METHODS}

This type of research is a descriptive study with a purposive sampling method. The population is all pregnant women at Bungah Public Health Center in Lamongan Regency from May to June 2019, amounting to 98 pregnant women with a sample calculation using the Slovin formula. The results of the sample size count in this study were 54 respondents. The inclusion criteria were pregnant women who were controlled at the Bungah Community Health Center in Gresik Regency from May to June 2019 and did not have a history of menstrual disorders (hypermenorrhea). The variable is knowledge about the post-placental IUD contraceptive method (Intra Uterine Device) in pregnant women. The data were collected using a questionnaire sheet consisting of 20 statements about IUD contraception (definition, working method, indication, contra indication, and installation). score 1 if the answer is wrong and score 2 if the answer is correct. Conclusion when answering the correct statement: lack of knowledge if the total score $<56 \%$ answers, knowledge is sufficient if the answer is $56 \%$ $75 \%$ correct, and good knowledge a total score of $76 \%-100 \%$ of all statements Processing data using editing, scoring, coding, tabulating and presented in a narrative form then draw conclusions. 


\section{RESULTS}

Table 1. Distribution of Respondents based on Education for Pregnant Women in the Bungah Community Health Center, Gresik Regency in 2019

\begin{tabular}{cccc}
\hline No & Educational level & Frequency & Percentage (\%) \\
\hline 1. & Elementary School & 8 & 14,8 \\
2. & Junior high school & 14 & 25,9 \\
3. & Senior high school & 28 & 51,9 \\
4. & College & 4 & 7,4 \\
\hline & Total & $\mathbf{5 4}$ & $\mathbf{1 0 0}$
\end{tabular}

The table shows that More than part of the respondents had a high school education and a small proportion have a tertiary education.

Table 2. Distribution of Respondents based on Age of Pregnant Women in the Bungah Community

\begin{tabular}{|c|c|c|c|}
\hline No & Age & Frequency & Percentage (\%) \\
\hline 1. & $<30$ years old & 12 & 22,3 \\
\hline 2. & $30-35$ years old & 32 & 59,2 \\
\hline 3. & $>35$ years old & 10 & 18,5 \\
\hline & Total & 54 & 100 \\
\hline
\end{tabular}

The table shows that almost part of the respondent was between 30 - 35 years old, and a small proportion is more than 35 years old.

Table 3. Distribution of Respondents Based on Parity of Pregnant Women in the Bungah Community Health Center, Gresik Regency in 2019.

\begin{tabular}{cccc}
\hline No & Profession & Frequency & Percentage (\%) \\
\hline 1. & 0 & 11 & 20,4 \\
2. & $1-2$ & 25 & 46,3 \\
3. & $\geq 3$ & 18 & 33,3 \\
& & & $\mathbf{1 0 0}$
\end{tabular}

The table shows that almost half of the respondents are parity or have pregnancy to $1-2$, and a small proportion of parity are 0 or have not had children.

Table 4. Knowledge Distribution About the Post Placenta IUD (Intra Uterine Device) Contraception Method for pregnant women in the Bungah Community Health Center, Gresik Regency in 2019.

\begin{tabular}{cccc}
\hline No & Knowledge & Frekuensi & Persentase (\%) \\
\hline 1. & Good & 4 & 7,5 \\
2. & Enough & 8 & 14,8 \\
3. & Less & 42 & 77,7 \\
\hline & Total & $\mathbf{5 4}$ & $\mathbf{1 0 0}$
\end{tabular}

The table shows that almost all respondents have less knowledge about the Post Placenta IUD (Intra Uterine Device) contraceptive method, and a small proportion have good knowledge.

\section{DISCUSSION}

This chapter will present the results of research that has been carried out to find out the knowledge of pregnant women about the IUD (Intra Uterine Device) Post Placenta in the Bungah Community Health Center, Gresik Regency.

Based on table 4, it shows that most respondents have less knowledge about the post placenta IUD contraceptive method. Knowledge about changes in the menstrual cycle is caused by several things, between education and the age of pregnant women.
According to Noto Atmodjo (2012), one of the factors that affect knowledge is age. With increasing age, there will be changes in physical and psychological (mental) aspects. In this study, most of the pregnant women were 20-35 years old. At this age it is included in the category of adult age. 30-35 years old is the reproductive age of the senate, which is considered mature for women in terms of emotion, personality and social. As you get older, you get more information and more experience. However, the results of this study show that many pregnant women do not know about Post Placenta IUD (Intra Uterine Device) 
contraception. This could be because they don't know much about contraception. IUD contraceptives are mostly done in basic health services, namely the postpartum IUD contraceptive method, namely the placement is done to postpartum mothers or post partum on the 40th day. Health promotion about IUD contraception needs to be socialized to women during pregnancy, especially during the last trimester. Health promotion can be done by using props, videos to provide a clear picture of IUD contraception.

Apart from age, another factor that can affect the knowledge of pregnant women about the Post Placenta IUD (Intra Uterine Device) contraceptive method is education. The results of this study Table 1 shows that more than half of the respondents have a high school education and a small proportion have a tertiary education (PT). The higher the level of education of pregnant women, the easier it is to obtain and capture the information provided, especially information that is positive in nature. Likewise, on the other hand, the lower the level of education, the more difficult it is for pregnant women to capture information and ideas about choosing a post-placenta IUD contraceptive method. In fact, this contraceptive does not require a time for installation during delivery and is a long-term contraceptive method with a usage duration of up to 10 years. Education is defined as all efforts that are planned to influence other people, be they individuals, groups or communities so that they do what is expected by education actors (Soekidjo Notoatmodjo, 2012).

According to Soekidjo Notoatmodjo (2012) knowledge is the result of knowing, and this happens after people sense a certain object. Sensing occurs through the human senses, namely the senses of sight, hearing, smell, taste and touch.

Human knowledge can be obtained through our senses, namely the eyes and ears. The better knowledge of a woman about IUD, hopefully can change the attitude and behavior of the woman to choose IUD as the contraception method. For pregnant women who have more than one parity or want to terminate their pregnancy, it is highly recommended to use this contraceptive. Likewise, on the contrary, lower knowledge can result in pregnant women not choosing the Post Placenta IUD (Intra Uterine Device) contraceptive method for various reasons that they put forward themselves without being based on sufficient knowledge. The more they are exposed to information by hearing, seeing, feeling, especially wanting to try it, they will gain a lot of knowledge but if they never make an effort to feel or see and hear about important information, it is certain that they will experience ignorance or lack of knowledge about the method. Post Placenta IUD (Intra Uterine Device) contraception.

Another factor that can influence knowledge is parity. Table 3 shows almost a partial parity of $1-2$. Pregnant women who have given birth will choose this contraceptive method because the use period is quite long, up to 10 years, so there is no need to continuously make visits to follow up the contraceptive method. The mother can independently check the thread position manually. Pregnant women who have given birth have experience in using the contraceptive method so that they can better understand the Post Placenta IUD (Intra Uterine Device) contraceptive method. The experience or knowledge gained will be more varied so that injection contraceptive mothers will feel confident that this contraceptive method is the appropriate method. Wahit lqbal Mubarok (2011).

\section{CONCLUSION}

Based on the results of research and discussion and research objectives regarding the knowledge of the Post-Placental Contraception Method for Pregnant Women at Bungah Public Health Center, Gresik Regency, it can be concluded as follows: almost all respondents have less knowledge of postplacental IUD contraceptive methods.

\section{REFERENCES}

A. Hary, Wied. (2011). Pengaruh informasi terhadap pengetahuan seseorang: Jakarta

Anna, Glasier. (2012). Keluarga Berencana Dan Kesehatan Reproduksi Edisi 4, Jakarta: EGC.

Alimul H, A.Aziz. (2011). Metodologi Penelitian Keperawatan Dan Teknik Analisis Data, Jakarta: Salemba Medika.

Arikunto, Suharsimi. (2013). Prosedur Penelitian (Suatu Pendekatan Praktek), Jakarta: PT Rineka Cipta

Barnett, C., Moehner, S., Do Minh, T., \& Heinemann, K. (2017). Perforation risk and intra-uterine devices: results of the EURAS-IUD 5-year extension study.

Benson, Ralph C. (2009). Buku Saku Obstetri Dan Ginekologi, Jakarta: EGC.

BKKBN. (2012). Evaluasi Program Kependudukan dan KB. Materi Rakerda Pembangunan Kependudukan dan KB Provinsi Jawa Timur.Gresik.

BKKBN Gresik. (2014). Profil hasil pendataan keluarga di daerah Gresik,Jawa Timur 
tahun (2014),Gresik: Badan Koordinasi Keluarga Berencana Nasional

Kemenkes RI. (2014). Profil Kesehatan Indonesia Tahun 2014. Jakarta.

Khopina, A. A., Efremova, S. A., \& Kurina, S. A. (1980). Characteristics of the vaginal microflora in healthy post-parturients in connection with application of intrauterine contraceptives in the early post-natal period. Sovetskaya Meditsina, 43(6), 88-91. Retrieved from https://www.scopus.com/inward/record.u ri?eid=2-s2.0$0018818807 \&$ partnerlD $=40 \& \mathrm{md} 5=3792$ 5771500b699164bfbd98669cf4b6

Mubarok, Wahit lqbal. (2011). Pengantar Keperawatan Komunitas 1, Jakarta: Sagung Seto.

Notoatmodjo, Soekidjo. (2012). Promosi Kesehatan Dan Perilaku Kesehatan, Jakarta: Rineka Cipta.

Saifuddin, Abdul Bari. (2011). Buku Panduan Praktis Pelayanan Kesehatan Maternal Neonatal, Jakarta:Yayasan Bina Pustaka Sarwono Prawirohardjo.

Sitorus, F. M., \& Siahaan, J. M. (2018). Pelayanan Keluarga Berencana Pasca Persalinan Dalam Upaya Mendukung Percepatan Penurunan Angka Kematian Ibu. Midwifery Journal: Jurnal Kebidanan UM. Mataram, 3(2), 114. https://doi.org/10.31764/mi.v3i2.505

UNDESA. (2019). Contraceptive Use by Method 2019. United Nations, 28. Retrieved from https://www.un.org/en/development/des a/population/publications/pdf/family/Cont raceptiveUseByMethodDataBooklet201 9.pdf

Wiknjosastro, Hanifa. (2010). Ilmu Kandungan, Jakarta: Yayasan Bina Pustaka Sarwono Prawirohardjo. 